Article

\title{
Appropriately Upset? A Methodological Framework for Tracing the Emotion Norms of the Transatlantic Security Community
}

\author{
Simon Koschut \\ Otto Suhr Institute for Political Science, Freie Universität Berlin, 14195 Berlin, Germany, E-Mail: simon.koschut@fu-berlin.de
}

Submitted: 28 March 2018 | Accepted: 23 October 2018 | Published: 28 December 2018

\begin{abstract}
Emotions have been found to underpin the moral hierarchy of values and beliefs within and among groups by restraining undesirable attitudes and behavior. As such, emotions serve as potential indicators for analyzing whether or not certain norms are still deemed relevant. As Jon Mercer puts it: "One way to test for the presence of norms is to look for emotion". While the literature in International Relations (IR) generally accepts the emotional underpinnings of norms, there has been strikingly little elaboration of appropriate methods and criteria for studying the link between emotion and norms in IR. In this contribution, I suggest that socialization processes in a security community involve the internalization of appropriate rules of emotional expression or, in short, emotion norms. I propose that emotion norms can be historically traced via the emotional vocabulary and expressive rules derived from the production of texts. To do this, I searched for documents and treaties that serve as canonical texts for the collective self-conception and self-image of the transatlantic security community. As I hope to show, in these texts one can find substantial evidence of emotion norms, which designates these documents as 'emotional landmarks' that embody the emotional construction of the transatlantic emotional (security) community.
\end{abstract}

\section{Keywords}

emotions; methodology; norms; security community; transatlantic security community

\section{Issue}

This article is part of the issue "Interdisciplinary Approaches to Studying Emotions within Politics and International Relations", edited by Alex Prior (University of Leeds, UK) and Yuri van Hoef (Utrecht University, The Netherlands).

(C) 2018 by the author; licensee Cogitatio (Lisbon, Portugal). This article is licensed under a Creative Commons Attribution 4.0 International License (CC BY).

\section{Introduction}

How do members of international institutions exercise power and authority when they generally lack formal rules and norms? In this contribution, I argue that international institutions-more specifically the North Atlantic Treaty Organization (NATO)-are composed of emotion norms that set the frame for appropriate interpretations and meanings of emotional performance among its members, and thus incorporate sociocultural standards into the emotional lives of agents. Emotion norms provide intersubjective patterns of standardized emotional expressions that underpin collective meanings and beliefs, and thus constitute a particular community by setting it apart from others. What makes emotions political, and thus relevant for International Relations (IR), is their communitarian nature: the emo- tional connections between individuals and their respective communities (Hutchison, 2016; von Scheve \& Salmela, 2014).

To develop this argument, this article takes a social constructivist viewpoint for studying emotions in world politics (Harré, 1986). A social constructivist perspective argues that emotions are cultural products that owe their meaning and purpose to socially acquired feeling rules (Abu-Lughod \& Lutz, 1990; Averill, 1980; Hochschild, 1979). Social constructivist emotion theories are based on a shared set of interrelated ontological and epistemological assumptions that separate them from more conventional emotion theories. Whereas biological and cognitivist emotion theories stick to a subjective ontology of emotion, social constructivism shifts the analytical focus from their internal phenomenological perception of emotions and a psychological appraisal by in- 
dividuals to their representative articulation and communication within social spheres. This does not mean that a constructivist approach to emotions simply denies their phenomenological expression in the sense of physically perceived feelings or ignores the role of the body in enacting feeling rules. Social constructivists are less interested in the inner feelings and thoughts of individuals but instead focus on the socially shared emotional patterns within and between groups. Constructivists thus employ a social ontology of emotions that is less concerned with investigating the subjectivity but rather the intersubjectivity of emotions. From this social ontology of emotions follows a social epistemology. A social epistemology of emotions states that emotions, and the discourses and power relationships they disclose, can only be fully grasped within the collectively shared meaning systems and social worlds in which they are represented and known. To sum up, constructivist emotion researchers are interested in the particular sociocultural spaces in which emotions are contextualized, the institutional and discursive mechanisms through which they are expressed, and the prescriptive and purposive social functions they serve to include or exclude subjects from entering the boundaries of their respective communities.

This suggests an underlying functionalist role for emotions. That is, emotions are not simply socially constructed, but these emotions serve an important purpose by fulfilling a series of social functions for a community (e.g., producing solidarity, disciplining noncompliance, affirming moral order, clarifying social hierarchy, etc.). Conversely, resistance to comply with established emotional conventions challenges the very foundations of such communities and paves the way for undermining and transforming them (Fattah \& Fierke, 2009; Hutchison, 2016; Koschut, 2014). Such a communitarian theory of emotions can help unpack and resolve the puzzle of how communities manage and distribute authority and power, particularly when they lack formal or writtendown rules and norms.

\section{Towards a Methodological Framework for Studying Emotional (Security) Communities}

The concept of emotional community was originally developed by the historian Barbara Rosenwein. Emotional communities are "groups in which people adhere to the same norms of emotional expression and valueor devalue-the same or related emotions" (Rosenwein, 2006 , p. 2). Rosenwein looks at how emotional communities formed and vanished during the Early Middle Ages and shows how these communities emotionally linked together a particular group of actors through the expression of a particular set of collectively shared emotions. While her empirical focus lies on selected emotional communities at a particular point in time, she explicitly formulates her concept as being universally applicable, for all times and cultures including nation-states and the modern world, making it particularly relevant for the study of world politics (Rosenwein, 2010, p. 12).

An emotional community rests on shared "accepted modes of emotional expression" that can be methodologically traced through similar emotional styles and discourse (Rosenwein, 2006, p. 24). Such emotion norms provide the emotional fingerprint that makes one emotional community distinguishable from other emotional communities. The members of an emotional community may (and often do) disagree on a variety of issues. What remains important is that, in resolving their conflicts, members follow the use and expression of properly agreed emotion norms, e.g., when and how anger is an acceptable form of emotional expression. In such communities, emotions do not "float freely" but are managed by its members in a way that makes them more reliable (Flam, 1990). Emotional communities thus limit the availability of particular emotional expressions in a given situation and their impact on proper behavior. Finally, emotional communities may overlap and some members may be part of several emotional communities at the same time (Rosenwein, 2006, pp. 109, 199).

How can we study emotional communities in world politics? Rosenwein $(2006 ; 2010)$ considers emotional communities to be also "textual communities", in which people are linked together through shared discourse and narratives. From a methodological viewpoint, such textual and verbal utterances provide researchers with a promising way to make emotions empirically accessible for researchers. As Bleiker and Hutchison (2008, p. 128) note, "one of the most promising locations to study emotions is in the manner in which they are represented and communicated". The approach put forward here is to ask for a method of inquiry that involves careful attempts to analyze emotions via their representational meaning within social spheres. A promising way to study these representations, and thus gain access to emotional meanings, is through their explication in discourse (Koschut, 2017a, 2017b). Below, I suggest some elements that a methodology of emotional communities must entail.

\subsection{Gathering a Dossier of Sources}

Rosenwein (2006) started with groups of individuals that already lived a communal life. For this group, she compiled a broad array of sources. The focus here should be on emotions that are explicitly expressed or tacitly implied over a range of sources and within or across a coherent time period. This may include a variety of textual sources, including (but not limited to) official statements (speeches, press releases, parliamentary debates), legal texts (treaties, conventions, agreements), biographical texts (diaries, autobiographies, personal notes), media texts (newspaper articles, interviews, editorials), and even popular culture (poems, novels, songs). While the selection of texts ultimately depends on the research question, there are some things to consider when studying the emotions within these texts. While it is preferable 
to have several different utterances from the group, researchers have to ultimately make do with what is available. Another problem results from the temporal framing of texts. Emotional expressions during relatively brief and unstable periods, such as a crisis, are likely to be very different from those expressed during more stable periods. Finally, texts are highly contingent on their historical and cultural embedding. It is thus important to include a larger text-based analysis from the relevant time period under study as well as secondary sources to confirm or disconfirm the findings and/or to detect changes in emotional meanings and expressions.

\subsection{Establishing Patterns and Meanings}

Once the researcher has managed to gather a satisfactory dossier of sources, the next step would be to extract emotion words from them and to assemble similar emotion words into dossiers. Here, it is important to keep in mind that emotions are often expressed implicitly, for example through imagery, figurative speech or connotations. Concepts such as genocide, terrorist, rogue state, outlaw, massacre not only carry a negative appeal but they also refer indirectly to specific emotions of disapproval such as anger and contempt. By contrast, emotional connotations such as peaceful, freedom fighter, hero, honest broker, responsible member of the international community indicate a different emotional attitude. Or consider the emotional underpinnings of metaphors. For example, to speak of floods of refugees produces fear among members of a community through a linguistic dehumanization of refugees. Thus, in addition to paying attention to emotion terms like fear, it is equally important to pay attention to borrowings and imagery in emotional language, such as metaphors or figures of speech. Also, the meanings resulting from emotional expressions are often sociocultural constructs and may thus resonate differently from culture to culture. Finally, it is equally important to read the silence (the emotion terms that are avoided) and how different kinds of silences can hold different kinds of emotional experiences.

\subsection{Tracing the Cultural Script}

Having established significant patterns and meanings of emotional expressions, the researcher will then be able to trace the cultural script and thus uncover the system of feelings underlying emotional communities. It is not sufficient to establish a set of emotion words. Rather, the weight and significance of these words needs to be examined: "what these communities (and the individuals within them) define and assess as valuable or harmful to them; the evaluations they make about other's emotions; the nature of the affective bonds between people that they recognize; and the modes of emotional expression that they expect, encourage, tolerate, and deplore (Rosenwein, 2002, p. 842). Researchers who wish to trace the emotion norms of a particular emotional com- munity need to consider which emotions are most fundamental to their styles of expression and sense of community. This may be achieved through two types of methods, both of which can be easily combined. In putting the dossier together, one might establish the frequency of particular emotion words with a quantitative evaluation or simple word count. Another way would be to conduct a qualitative interpretation of particular emotion words or their lack as part of a larger cultural framework.

\subsection{Detecting Change over Time}

Emotions are neither inherently moral nor beyond the scope of moral consideration, but they are deeply rooted in the collective values and beliefs of communities. By tracing such emotions, we can learn a lot about the values and moral meanings of these communities. But emotional communities are also subject to change. Emotions can change and sometimes vary significantly in their historical meaning and cultural expression. A fruitful strategy to analyze norms and their social consequences is to conduct a broad historical analysis that is able to retrieve identifiable patterns of emotional expressions that might tell us something about how emotion norms - the expression of appropriate emotions in a given situation-have come to be constituted in their current form. A promising research strategy to develop such a genealogy of standardized emotional expressions over time is to historicize them. To historicize emotions means "subjecting discourses on emotion, subjectivity, and the self to scrutiny over time, looking at them in particular spatial locations and historical moments, and seeing whether and how they have changed" (AbuLughod \& Lutz, 1990, p. 5). The sociologist Norbert Elias (1939/1994), for example, suggests in his seminal work on the history of emotions that standards of emotional expressions gradually changed in the course of a long "civilizing process" in Western societies. Building on Elias (1939/1994), IR scholars such as Linklater (2014, p. 574) argue that increasingly pacified political communities in the Western world have tabooed open displays of anger since anger is regarded as triggering violence.

\section{Tracing the Emotion Norms of the Transatlantic Security Community}

In this contribution, I suggest that emotional socialization in a security community involves the internalization of appropriate rules of emotional expression-or emotion norms. The concept of security community was introduced to IR by Karl W. Deutsch in 1957, describing it as a regional system of independent states that is characterized by such high levels of amity and patterns of social communication and interaction that war between its members becomes virtually inconceivable. Since then, many scholars have made use of the concept and expanded its original scope, broadened its empirical use and positioned it as an alternative concept 
to other forms of security governance and peaceful orders such as alliances, regimes, international organizations, and imperial orders. Emanuel Adler and Michael Barnett's (1998) path breaking book is perhaps the most well-known scholarly work among many others. This impressive attention to the concept and workings of security communities in IR, however, has not included a sustained consideration of emotions. Deutsch's magnificent work on security communities was largely devoid of a substantial treatment of emotions. This is not to argue that Karl Deutsch did not pay attention to the emotions. Deutsch's philosophical assumptions on human reason included a firm belief that the essential political and economic questions of world politics lie beyond the rational-choice paradigm and instead "are at bottom moral and spiritual" (Deutsch, 1967, p. 64). As Donald Puchala (1981, p. 151) notes in his reflections on Deutsch's theory of integration: "Deutsch's most important contribution to the study of international integration are in his findings concerning sentimental relations among peoples". Deutsch found human behavior to result from the interplay of reason and emotion arguing that people "is a community of rational beings united in the object of their love". The fact that Deutsch explicitly refers to the emotions demonstrates his awareness of their constitutive role in shaping social life. As he notes in his description of the North Atlantic area, there exists a "Western' way of life which is so often felt and referred to" (Deutsch et al., 1957, p. 134). In fact, Deutsch goes as far as to conceive of collectively shared emotions as a necessary condition of a security community formation because this makes it more resistant to managing crises: "The kind of sense of community that is relevant for integration, and therefore for our study, turned out to be rather a matter of mutual sympathy and loyalties; of 'we-feeling', trust, and mutual consideration...in short, a matter of a perpetual dynamic process of mutual attention, communication, perception of needs, and responsiveness in the process of decision-making. 'Peaceful change' could not be assured without this kind of relationship" (Deutsch et al., 1957, p. 36). "We-feeling" describes the formation of an emotional bond among members of the security community that underpins social belonging to this particular group, or as Deutsch put it: "common subjective feelings of the legitimacy of the integrated community, making loyalty to it also a matter of internalized psychic compulsion" (Deutsch, 1966, p. 241). In other words, members of security community conceive themselves as part of an emotional community, in the sense that they feel as a community.

Attributing emotions, or emotion norms to an international institution, such as NATO, is not an uncontroversial position. It raises fundamental questions concerning the level of analysis and conceptual scope of studying security communities as emotional communities. Many of these conceptual issues have been dealt elsewhere (Koschut, 2014). This article is more concerned with the practical and methodological ways to operational- ize emotions. Still, since the article relates directly to normative emotional discourses and the legitimization of emotion norms, the emotion-knowledge-power nexus needs to be further addressed here. Understanding security communities as emotional communities points to the epistemological centrality of emotional knowledge. Emotional knowledge is an agent's ability to cognitively and morally categorize emotional expressions and to emotionally connect these affective categories to Others' identities based on experience over time (Frevert, 2011). In other words, members have to be able to know what it means to be angry, ashamed, or happy in order to understand its social implications and evoke appropriate emotional reactions toward others within a particular social situation based on previous experience and moral judgments. For example, anger can be interpreted as destructive to close relationships because one may have experienced the destructive nature of anger in previous relationships. At the same time, anger may be perceived as displaying the closeness of a relationship based on a very different emotional experience.

Emotional knowledge is based on intersubjective learning, i.e., the habituated establishment and recurring exchange of emotions that shape the identities of social actors. One member communicates emotions to other members who then give emotional feedback and, in turn, receive emotional feedback on their part, and so on. Through this perpetuating process of emotional socialization, members of an emotional (security) community can enter a stage of understanding by building a common emotional history together which contributes to the establishment of shared meanings and even trust (Oatley \& Jenkins, 1996, p. 181). In sum, emotional knowledge is about orientation and meaning. It is the accumulation of memories, founding myths, experiences, and symbolic patterns that enables members to make sense of the world around them within an emotionally shared reality.

Process sociology has shown how emotional knowledge forms part of asymmetries of power and status in which "established" groups secure the compliance of outsiders (Elias \& Scotson, 1965). Insiders maintain and reproduce a particular self-image of social superiority vis-à-vis outsiders based on group charisma and emotional knowledge (feeling of social superiority/pride). At the same time, established groups persuade outsiders to internalize feelings of social inferiority (shame) through emotional rigidity, stigmatization, and by placing the contact of insiders with outsiders under a taboo. Accordingly, contact with outsiders is associated with negative feelings. Through these figuration processes, 'inside' groups exercise and maintain a power asymmetry that is rooted in emotional knowledge (Elias \& Scotson, 1965 , pp. 8, 12).

Inside an emotional (security) community, members are not treated as approximate equals but are woven together in asymmetrical power relationships. The selfimage of the established group is formed based on the minority of its 'best' members (core group). This 
core group performs a norm building function and exercises power over potential or actual norm breakers through control and stigmatization (Elias \& Scotson, 1965 , pp. 13, 42). Members can only participate in an emotional community by complying with certain emotional patterns of affect control. Members who do not comply by siding with or showing sympathy toward outsider groups will risk losing their power and status within the "inside" group. In other words, the core group is able to teach and enforce emotion norms. The notion of a core group corresponds nicely with Deutsch's notion of "cores of strength" within a security community. Security communities develop around cores of strength that possess material and moral authority due to their superior material power, international legitimacy, and acquired norms and practices (Adler, 2001, p. 147; Deutsch et al., 1957, p. 28). In the transatlantic (emotional) security community, it seems fair to suggest that the US forms such a core. In sum, processes of emotional socialization involving power and status are constantly present in an emotional (security) community and reproduced through knowledge: less superior members assimilate in relation to more powerful core groups, rivaling other members for status and power, shaping and reshaping their emotional experience and group charisma, or responding in ways that satisfy other members (Elias, 1939/1994). Hence, emotional knowledge and power are interwoven: communicating and transferring emotional knowledge within and between groups constitutes and maintains power relationships.

The emotion norms in the transatlantic security community will be empirically traced here on the inside as well as on the outside. Accordingly, the case study is structured into two parts. First, the presence and effects of the inside emotion norm of amity will be shown. Second, the case study will switch perspective by looking at the outside emotion norm of enmity expressed by the same community members. The empirical analysis will mainly focus on key documents and elite discourse among political leaders. Political leaders are defined here as "responsible decision-makers" having a political mandate in one form or another which includes heads of state, heads of governments, cabinet members and other elected representatives (Hill, 2003). Since political leaders are publicly mandated representatives of their respective state one would expect them to internalize (at least to a significant extent) the emotion norms of the emotional (security) community (Eznack, 2012, p. 242).

It is fair to suggest that many political leaders may simply not show their "true" emotions unless it is politically opportune. Thus, the emotional expressions (or lack thereof) on the surface may not necessarily reflect what these individuals feel underneath. Obviously, it is impossible to look into the heads of political decision makersbe it interests, ideas, or emotions and this article is no exception to that. Even though these limitations are real they do not make the empirical analysis irrelevant. The main task of this article is to show that emotions have a binding role in social arrangements at different levels of world politics. It is thus less interested in emotional patterns within individual political leaders but more inclined to trace emotional patterns between individual political leaders and the societies they represent. This conception can be based on Elias concept of 'figuration': "The social fabric and its historical change are not chaotic but possess, even in phases of greatest unrest and disorder, a clear pattern and structure. To investigate the totality...does not mean to study each individual process within it. It means first of all to discover the basic structures which give all the individual processes...their direction and their specific stamp" (Elias, 1939/1994, p. 400). A similar argument can be found in the concept of emotionology, which distinguishes the collective emotional standards from personal emotional experiences (Stearns \& Stearns, 1985, p. 813).

It is argued here that inside a security community, members value and encourage emotions that emphasize the norm of amity like empathy, pride, gratitude, honor, respect, compassion, and sympathy. At the same time, they tend to discourage or show restraint toward emotional expressions that stress the norm of enmity such as fear, disgust, hatred, jealousy, and rage. Outside the security community, members collectively express emotions that are compatible with the norm of enmity, such as anger or fear, toward those non-members that are perceived as threatening or incompatible with the community's "way of life". What is of importance to the argument developed here is that a combination of particular emotional expressions (and their meaning) directed inwards, and reserved exclusively for the members of the emotional community, and particular emotional expressions directed outwards, contribute to the consolidation and stability of the community during crises (Koschut, 2014). Based on this inside/outside dualism, the emotion norms of an emotional (security) community are categorized here as amity (inside) and enmity (outside).

\subsection{Inside Emotion Norm: Amity}

Amity produces durable bonds, reliability, and trust in at least three ways. First, it assures a "distinctive way of life" and a sense of belonging that sets the community apart from other areas and regions including the one they previously inhabited (Deutsch et al., 1957). The development of such a way of life is closely related to the social construction of a collective identity, a sense of community or "we-feeling" in a security community (Adler \& Barnett, 1998). Second, amity encourages community members to respond to each other's needs, messages, and behavior in a way that enables members to resolve their conflicts peacefully. Finally, through processes of social learning the emotional expressions of community members align in a way that enables them to predict one another's intentions and, ultimately, to overcome feelings of uncertainty. As van Hoef and Oelsner (2018) 
also argue in this issue, this alignment of collectively expressed emotions serves as a background condition for peaceful interaction by developing shared moral meaning. In an emotional (security) community, members feel secure through an intensified emotional state of connectedness and belonging: they "lose their selves in the others" (Flam, 1990, p. 48). In sum, the norm of amity performs important functions within an emotional (security) community: it encourages mutual commitment, responsiveness, and predictability and thus contributes to the stabilization of collective identification and mutual trust.

The emotion norm of amity can be historically traced via the emotional vocabulary and expressive rules from the production of texts. In order to do this, I searched for documents and treaties that can be said to have served as canonical texts or monuments for the self-conception and self-image of the transatlantic security community. For this purpose, I chose the North Atlantic Treaty of 1949 (which is also known as the Washington Treaty) and the Statement by the North Atlantic Council on the Invocation of Article 5 on September 12, 2001. Both texts constitute central reference points as seminal historical moments for the transatlantic security community. The Washington Treaty forms the foundational charter of the transatlantic security community. The Statement on the Invocation of Article 5 marks the first time the transatlantic security community formally activated the collective defense clause. In these texts, one can find substantial evidence of the emotion norms of amity, which designates these documents not only as textual monuments but, significantly, also as emotional landmarks that embody the emotional knowledge and norms of the transatlantic emotional (security) community.

First, in the preamble of the Washington Treaty (NATO, 1949), NATO members pledge to promote "wellbeing" in the North Atlantic area. Well-being obviously implies not just material benefits but, importantly, also a psychological state of emotional well-being, free from fear or anxiety. Both conceptions, "to live in peace" and "well-being" arguably form the raison d'être for the Atlantic community. Significantly, they are rooted not just in cognitive beliefs about the shared history and values of a socially constructed "North Atlantic area", but in shared emotional beliefs of overcoming mutual suspicion and fear (the security dilemma) as well as creating a state of confidence and trust among its members (the security community). In the Washington Treaty, "peace" and "well-being" is consequently equated with feelings of pleasure ("desire"), feelings of purpose ("to safeguard freedom"), and a social connection of mutual belonging ("the common heritage and civilization of their peoples"). In the subsequent treaty articles, one finds further traces of emotional expressions that reinforce amity. For example, in Articles 2 and 3, respectively, members express emotional feelings of amity by emphasizing the "friendly" (sympathy, respect) character of their relationship and the goal to promote "better understanding", "mutual aid" and "encouragement" (care-taking, com- passion, empathy) among them. Mutual "consideration" and "respect" is voiced explicitly in Articles 9 and 11, respectively, implying not only a pledge "to consult together" about matters of common interest but also a willingness to take the feelings of other members into account before taking action in order to avoid making fellow members feel upset or angry. All of these aspects can be said to promote a "we-feeling" among members of the transatlantic security community that is reinforced by frequent references to solidarity and unity ("resolved to unite", "encourage...collaboration", "assist", "in concert"). The most important aspect, however, is the principle of collective defence enshrined in Article 5 of NATO's founding treaty, which bears a highly symbolic and sacred quality to NATO members. As the official website of NATO (2018) explains:

The principle of collective defence is at the very heart of NATO's founding treaty. It remains a unique and enduring principle that binds its members together, committing them to protect each other and setting a spirit of solidarity within the Alliance.

In a Durkheimian sense, the principle of collective defence resembles a cultural totem that reflects the security community's collective sense of purpose, arouses intense emotions, and reinforces metaphysical beliefs of mutual trust and solidarity (Durkheim, 1912/2001).

Second, the statement by the North Atlantic Council (NATO, 2001) on the historical occasion of invoking Article 5 of the Washington Treaty in response to the September 11th attacks on the United States puts the emotion norm of amity into practice. As pointed out above, since the principle of collective defence enshrined in Article 5 constitutes a sacred quality for the members of the security community as well as the symbolic manifestation of mutual trust and collective identity, its invocation (and above all, for the first time in its 52-year history) should arouse very intense emotions that can be traced in the text of the statement. Moreover, these emotional expressions conveyed in the text should reiterate the emotion norm of amity. Indeed, a closer study of the statement on the invocation of Article 5 in 2001 reveals just that. NATO members begin by emphasizing that even though the principle of collective defence had been originally designed to protect European members from Communist attack, "it remains no less valid and no less essential today". This "commitment" suggests an emotional state of being dedicated to a common cause and a pledge to honour a joint obligation. Another emotional reference to the emotion norm of amity is stated when NATO members pay "tribute to the success of the Alliance in ensuring the freedom of its members during the Cold War and in making possible a Europe that was whole and free". Here, we can trace not only the emotional expression of pride in the collective accomplishments of the transatlantic security community but also underlying gratitude among European member 
states whose safety had been guaranteed by the United States throughout the Cold War. Most importantly, the statement expresses shared sympathy and mutual joy about the unbroken bonds among NATO members in the face of a new threat. This notion is reinforced by members' "reaffirmed...determination", their "commitments to one another" and their pledge to "stand ready to provide the assistance". Ten years on, this "we-feeling" continued to feature prominently when the members of the North Atlantic Council (NATO, 2011) reflected on the occasion of the 10th Anniversary of the Invocation of Article 5: "This decision was a powerful expression of transatlantic solidarity and unity...NATO and our partner nations from across the world can be proud of what we have achieved". The basic connotation of this statement suggests an attitude of "we stand together and nothing can divide us".

As these examples from two key transatlantic texts illustrate, amity among members of an emotional (security) community is chiefly expressed through collective emotions of care, sympathy, compassion, pride, honor, gratitude, and respect. The expression of care and sympathy protects its members against indifference by feeling along with each others' distress and by "being there" or caring for each other in symbolic and material ways (the mutual defense clause comes to mind). Pride and honor reinforce the confidence among members that they deserve and value the privileges and virtue of superiority that is associated with group membership ("the most successful defensive alliance in history"). Gratitude and respect both serve as an emotional commitment to reciprocate in the future. Members of a security community do not expect to be "paid back" immediately but base their exchanges of support and caring on need, not on payback.

\subsection{Outside Emotion Norm: Enmity}

Enmity builds trust among members of an emotional security community by setting insiders apart from outsiders and thereby generating internal cohesion. Disconnecting insiders from outsiders is an act of identity building necessary for developing and maintaining a security community (Adler \& Barnett, 1998, p. 38). In an emotional (security) community, amity and enmity are two sides of the same coin. Collective identification in a security community cannot be treated in isolation but can only be fully understood if viewed as an emotional construction of a (or multiple) shared "disgusting Other(s)" (Leep, 2010). Such a shared Other must not exclusively be defined in strictly military terms such as an outside military threat but contains a much broader concept based on regime type (e.g., democracy vs. non-democracy), cultural or religious differences (e.g., Occident vs. Orient), and/or spatial concepts (e.g., the Atlantic area vs. the Pacific rim). Thus, the norm of enmity must not primarily be defined in terms of material or physical coercion but rather in terms of a perceived risk or harm to the distinctive "way of life" of an emotional (security) community.

It is certainly not suggested that all outsiders are considered a threat. It does emphasize, however, that such inside/outside configurations sharpen the moral boundaries between insiders and outsiders. This is particularly the case in crisis situation when members of an emotional (security) community become "locked into" an insider-outsider dualism that is hard to disrupt and leaves little room for differentiation. It is also important to point out that this configuration does not negate the possibility of new members to join. It does suggest, however, that these new members will enter the community not as approximate equals but as members with inferior status and power vis-à-vis established members.

The same landmark texts cited above indicate many emotional expressions of the emotion norms of enmity that complement the emotion norms of amity. First, the Washington Treaty addresses the need "to safeguard" the values and principles shared in the North Atlantic area, which implies an emotional feeling of fear or anxiety that outsiders might undermine or harm the community's "way of life". A similar emotional expression of fear and anxiety is used in Articles 1 and 4, respectively. Here, members voice their concern that peace and the security of any member shall not be "endangered" or "threatened". The most vivid expression of the emotion norm of enmity can be found in NATO's collective defense clause. Article 5 of the Washington Treaty explicitly mentions an "armed attack" by outsiders: "The Parties agree that an armed attack against one or more of them in Europe or North America shall be considered an attack against them all". An armed attack implies emotional feelings of anger or even hatred attributed to outsiders because the very word "attack" suggests an aggressive and violent intention that may cause great suffering and pain. By pledging to collectively resist such an attack by outsiders, members simultaneously express a sense of community and "we-feeling" ("shall be considered an attack against them all"), perhaps even gratitude (mutual defense is a commitment that they make for each other in the future), that, in turn, reinforces the emotion norms of amity and reduces unwanted emotions for the in-group, such as fear or anxiety. This discursive pattern can be found several times in the document and, as we shall see, in many other NATO documents and statements as well. The emotional-linguistic structuring of texts in emotional communities very often employs emotional expressions of enmity to reinforce and strengthen the emotion norm of amity, for example by contrasting compassion with contempt ("mutual aid...to resist attack") or empathy versus fear ("consult together whenever...any of the Parties is threatened"). Underlying this pattern is the idea of triggering an emotional upward spiral that increases the confidence and trust that members invest in the community, while simultaneously reducing or even eliminating feelings of uncertainty and fear. 
Second, the Statement by the North Atlantic Council on the Invocation of Article 5 contains very intense emotional expressions that more directly reflect the emotion norm of enmity. For example, NATO members "condemn" the "appalling attacks" and "acts of barbarism" that were "perpetrated" against the United States. The latter verbal use of perpetrate constitutes an emotional reference to dishonourable behaviour by someone else. This statement represents a vivid case of emotional Othering (a "disgusting Other") by strategically employing emotional expressions of contempt and anger against particular outsiders (see also Sanchez Salgado, 2018, in this issue). This is further underlined when NATO members refer to the "scourge of international terrorism". By employing a synonym for something extremely evil and menacing, NATO members express emotions of contempt and anger against a radical Other. At the same time, they reveal emotional expressions of fear and grief by referring to $9 / 11$ as an event that caused great suffering. Likewise, the mentioning of "appalling attacks" exposes emotional expression of fear in response to aggressive action by enemy forces coupled with an affective adjective emphasizing grief for the victims of the attacks.

As these examples illustrate, enmity toward outsiders is expressed through collective emotions of fear, anger, contempt, and jealousy. Fear alerts members to an imminent danger focusing attention on the source of the threat. Jealousy mobilizes members to protect their values and attachments against outsiders. Anger and contempt reinforce attachment to community values by activating collective emotions against other groups or life styles that seem to work against the values of the security community. The emotion norm of enmity is particular evident when members of a security community practically engage in military interventions against outsiders, as Gray (1959, p. 146) explains: "We cannot fight without an image of the enemy as totally evil, for whom any mercy or sympathy is incongruous, if not traitorous". In other words, the emotion norm of enmity "closes the ranks" by focusing attention on the negative attributes of outsiders.

To sum up, the emotion norms of amity and enmitya combination of particular emotional expressions (and their meaning) directed inwards and reserved exclusively for the members of the emotional community, and particular emotional expressions directed outwardsundergird and strengthen the transatlantic security community. Emotions underpin the distinct set of values and beliefs "that makes up much of that 'Western' way of life which is so often felt and referred to" (Deutsch et al., 1957, p. 134).

\section{Conclusion}

In this contribution, I advanced the argument that social relations between members of a security community resemble an emotional community. I sought to demonstrate how security communities are constituted through the development and expression of emotion norms and proposed that emotion norms can be historically traced via the emotional vocabulary and expressive rules derived from the production of texts. In the end, this contribution advocates investing more research into the practical ways to study emotions empirically. We cannot allow methodological conventions and epistemological "fist-fighting" to cut us off from emotions' less easily detected effects simply because conventional social science methods cannot account for all aspects of emotion. Instead, we need concrete tools and techniques as well as greater cross-fertilization across areas of specialization - a "thinking without a banister" (Arendt, 2018)-within the discipline of IR, and the social sciences more generally. Proposing such a methodological toolkit, I drew on linguistic accounts as well as interpretative approaches by historians to advance the development of concrete research tools and methods that would facilitate cross-disciplinary inquiries, overcoming existing methodological hurdles. As envisioned by the editors of this special issue, such an interdisciplinary focus offers an ideal way that builds on and enters into dialogue with other disciplines, including Psychology, Sociology, History, and Anthropology. In the end, this approach entails two paradigmatic shifts: first, understanding security communities as emotional (security) communities that are guided by collectively shared emotion norms forces a conceptual rethinking about our knowledge of the internal mechanisms within these groups and contributes to a wider debate about the socio-psychological and emotional foundation of world politics. Second, it offers a radical departure from the overwhelming dominance of the rational actor paradigm in much of the social sciences, which has stood in the way of taking emotions seriously.

\section{Acknowledgments}

This research has been funded by the German Research Foundation (DFG) as part of the research network Constructivist Emotion Research (KO/4078/3-1). An earlier version was presented at a workshop in Frankfurt/Main, Germany. I am grateful for very helpful comments and suggestions by Nicole Deitelhoff, Sassan Gholigha, Regina Heller, Inga Kravchik, Bastian Loges, Diana Panke, Elvira Rosert, Carmen Wunderlich and Lisbeth Zimmermann as well as by the editors and reviewers of this thematic issue.

\section{Conflict of Interests}

The author declares no conflict of interests.

\section{References}

Abu-Lughod, L., \& Lutz, C. A. (Eds.). (1990). Language and the politics of emotion. Cambridge: Cambridge University Press. 
Adler, E. (2001). The change of change: Peaceful transitions of power in the multilateral age. In C. A. Kupchan, E. Adler, J.-M. Coicaud, \& Y. F. Khong (Eds.), Power in transition: The peaceful change of international order (pp. 138-158). New York; NY: United Nations University Press.

Adler, E., \& Barnett, M. (Eds.). (1998). Security communities. Cambridge: Cambridge University Press.

Arendt, H. (2018). Thinking without a banister: Essays in understanding, 1953-1975. New York, NY: Schocken.

Averill, J. R. (1980). A constructivist view of emotion. In R. Plutchik \& H. Kellerman (Eds.), Emotion: Theory, research and experience (Vol. 1, pp. 305-339). New York, NY: Academic Press.

Bleiker, R., \& Hutchison, E. (2008). Fear no more: Emotions in world politics. Review of International Studies, 34(1), 115-135.

Deutsch, K. W., Burrell, S. A., Kann, R. A., Lee, M. Jr., Lichterman, M., Lindgren, E., \& Van Wagenen, R. W. (1957). Political community and the North Atlantic Area. International organization in the light of historical experience. Princeton, NJ: Princeton University Press.

Deutsch, K. W. (1966). The nerves of government. Models of political communication and control. New York, NY: Free Press.

Deutsch, K. W. (1967). Tides among nations. New York, NY: Free Press.

Durkheim, E. (1912/2001). The elementary forms of religious life. Oxford: Oxford University Press.

Elias, N. (1994). The civilizing process. Oxford: Blackwell. (Original work published 1939)

Elias, N., \& Scotson, J. L. (1965). The established and the outsiders: A sociological enquiry into community problems. London: Frank Cass.

Eznack, L. (2012). Crises in the Atlantic alliance. Affect and relations among NATO members. Basingstoke: Palgrave.

Fattah, K., \& Fierke, K. M. (2009). A clash of emotions: The politics of humiliation and political violence in the Middle East. European Journal of International Relations, 15(1), 67-93.

Flam, H. (1990). Emotional "man": I. The emotional "man" and the problem of collective action. International Sociology, 5(1), 39-56.

Frevert, U. (2011). Emotions in history-Lost and found. Budapest: Central European University Press.

Gray, J. G. (1959). The warriors: Reflections on men in battle. New York, NY: Harper \& Row.

Harré, R. (Ed.). (1986). The social construction of emotions. Oxford: Blackwell.

Hill, C. (2003). The changing politics of foreign policy. Basingstoke: Palgrave Macmillan.

Hochschild, A. R. (1979). Emotion work, feeling rules and social structure. American Journal of Sociology, 85(3), 551-575.

Hutchison, E. (2016). Affective communities in world politics. Cambridge: Cambridge University Press.
Koschut, S. (2014). Emotional (security) communities: The significance of emotion norms in inter-allied conflict management. Review of International Studies, 40(3), 533-558.

Koschut, S. (2017a). The power of (emotion) words: On the importance of emotions for discourse analysis in IR. Journal of International Relations and Development, 21(3), 495-522.

Koschut, S. (2017b). Introduction to forum: Discourse and emotions in international relations. International Studies Review, 19(3), 481-485.

Leep, M. C. (2010). The affective production of others. United States policy towards the Israeli-Palestinian conflict. Cooperation and Conflict, 45(3), 331-352.

Linklater, A. (2014). Anger and world politics. How collective emotions shift over time. International Theory, 6(3), 574-578.

North Atlantic Treaty Organization. (1949). The North Atlantic treaty. North Atlantic Treaty Organization. Retrieved from https://www.nato.int/cps/ic/natohq/ official_texts_17120.htm

North Atlantic Treaty Organization. (2001, September 12). Statement by the North Atlantic Council. North Atlantic Treaty Organization. Retrieved from https://www.nato.int/docu/pr/2001/p01-124e.htm

North Atlantic Treaty Organization. (2011, September 12). Statement by the North Atlantic Council on the occasion of the 10th anniversary of the invocation of article 5. North Atlantic Treaty Organization. Retrieved from https://www.nato.int/cps/ua/ natohq/news_77926.htm?selectedLocale=en

North Atlantic Treaty Organization. (2018, June 12). Collective defense-Article 5. North Atlantic Treaty Organization. Retrieved from http://www.nato. int/cps/en/natohq/topics_110496.htm

Oatley, K., \& Jenkins, J. M. (1996). Understanding emotions. Malden, MA: Blackwell.

Puchala, D. J. (1981). Integration theory and the study of international relations. In R. L. Merritt \& B. M. Russett (Eds.), From national development to global community. Essays in honor of Karl W. Deutsch (pp. 145-165). London: George Allen \& Unwin.

Rosenwein, B. H. (2002). Worrying about emotions in history. American Historical Review, 107(3), 821-845.

Rosenwein, B. H. (2006). Emotional communities in the early Middle Ages. Ithaca, NY: Cornell University Press.

Rosenwein, B. H. (2010). Problems and methods in the history of emotions. Passions in Context. Retrieved from http://www.passionsincontext.de/uploads/ media/01_Rosenwein.pdf

Sanchez Salgado, R. (2018). The advocacy of feelings: Emotions in EU-based civil society organizations' strategies. Politics and Governance, 6(4), 103-114.

Stearns, P. N., \& Stearns, C. Z. (1985). Emotionology: Clarifying the history of emotions and emotional standards. American Historical Review, 90(4), 813-836.

Van Hoef, Y., \& Oelsner, A. (2018). Friendship and posi- 
tive peace: Conceptualising friendship in politics and international relations. Politics and Governance, 6(4), 115-125.

\section{About the Author}



Simon Koschut is currently a Visiting Professor in International Relations and European Integration at the Otto Suhr Institute at the Freie Universität Berlin, Germany. Starting in 2019, he will begin a Heisenberg Research Fellowship funded by the German Research Council (DFG). His book Normative Change and Security Community Disintegration (Palgrave Macmillan 2016) received the Ernst Otto Czempiel Award 2018 for the best postdoctoral monograph published in the field of peace research (www.simon-koschut.com). 